\title{
Walking stability of Rhyzopertha dominica (Fabricius, 1792) (Coleoptera: Bostrichidae)
}

\author{
E. M. Pires ${ }^{a *}$, R. M. Nogueira ${ }^{a}$, D. S. Pina ${ }^{a}$, C. L. M. Manica ${ }^{a}$, \\ L. R. A. Faroni ${ }^{b}$ and P. S. A. Moreira ${ }^{a}$ \\ aniversidade Federal de Mato Grosso - UFMT, Campus de Sinop, Av. Alexandre Ferronato, 1200, \\ Setor Industrial, CEP 78550-000, Sinop, MG, Brazil \\ ${ }^{b}$ Universidade Federal de Viçosa - UFV, Av. PH Rolfs, s/n, Centro, CEP 36570-000, Viçosa, MG, Brazil \\ *e-mail: evaldo.pires@gmail.com
}

Received: August 19, 2014 - Accepted: May 16, 2015 - Distributed: August 31, 2016

(With 3 figures)

\begin{abstract}
Results obtained in studies can contribute to the advancement of science and innovative methods and techniques for developing practical activities. Reporting conditions that may restrict the implementation of research is critical to ensure the optimal development of further technical studies. The objective of this study was to assess the walking stability of $R$. dominica on a flat and smooth surface. The study was based on the determination of mortality, morphology and walking stability of the insect outside the grain mass, on a flat and smooth surface. Mortality of adults of this Coleoptera in conditions with and without food was similar, which explains the difficulty that this insect had for accessing the food source on the flat and smooth surface. The measurements of body length (BOL), width (BOW) and height (BOH) of $R$. dominica were compared with those of Tribolium castaneum (Coleoptera: Tenebrionidae), which showed good ability to walk in these conditions. This study indicated that the former presents lower BOL and BOW, and greater $\mathrm{BOH}$ than the second, and all these variables showed differences when analyzed simultaneously by means of the construction of multivariate morphometric indices (Width $\times$ Height, Length $\times$ Height and Height $\times$ Length $\times$ Width). These morphometric variables, together with the definition of the geometry most similar to the body shape, resulted in determination of the center of gravity $(\mathrm{CG})$ and static rollover threshold $\left(S R T_{\text {geom }}\right)$ for both species. Rhyzopertha dominica and T. castaneum presented CGs considered high and low, respectively, and together with the values obtained for $S R T_{\text {geom }}$, may justify that $R$. dominica can be considered a less stable species during movement, and presents greater risk of rollover on flat and smooth surfaces.
\end{abstract}

Keywords: bioassays, center of gravity (CG), coefficient of friction, rollover, grain pests.

\section{Estabilidade de caminhamento de Rhyzopertha dominica (Fabricius, 1792) (Coleoptera: Bostrichidae)}

\section{Resumo}

Resultados obtidos em pesquisas podem contribuir com o avanço da ciência e inovar métodos e técnicas para o desenvolvimento de atividades práticas. Relatar condições que podem restringir à execução de pesquisas é fundamental para garantir que seja observada a técnica ideal para o desenvolvimento de estudos posteriores. O objetivo deste trabalho foi estudar a estabilidade de caminhamento de $R$. dominica em superfície plana e polida. O estudo se baseou na determinação da mortalidade, morfologia e estabilidade de caminhamento do inseto fora da massa de grãos, em superfície plana e polida. A mortalidade dos adultos desse Coleoptera nas condições com e sem alimento foram semelhantes, o que justifica a dificuldade que esse inseto tem em acessar a fonte alimentar andando em superfície plana e polida. As medidas obtidas do comprimento (BOL), largura (BOW) e altura (BOH) do corpo de R. dominica foram comparadas com as de Tribolium castaneum (Coleoptera: Tenebrionidae), que pode ser considerado um bom caminhador nessas condições. Esse estudo mostrou que o primeiro é menor no BOL e BOW, e maior BOH que o segundo, e que, todas essas variáveis apresentaram diferenças quando analisadas simultaneamente por meio da construção de índices morfométricos multivariados (Largura $\times$ Altura; Comprimento $\times$ Altura e Altura $\times$ Comprimento $\times$ Largura). Essas variáveis morfométricas, juntamente com a definição da forma geométrica que mais se aproxima do formato corporal, proporcionaram a determinação do centro de gravidade (CG) e do limite lateral de tombamento $\left(S R T_{\text {geom }}\right)$ para ambas as espécie. Rhyzopertha dominica e T. castaneum apresentaram CGs considerados alto e baixo, respectivamente, e juntamente com os valores obtidos para os $S R T_{\text {geom }}$, podem justificar que $R$. dominica pode ser considerada uma espécie menos estável durante o caminhamento, e que, apresenta maiores riscos de tombamento em superfícies plana e polida.

Palavras-chave: bioensaios, centro de gravidade (CG), coeficiente de atrito, tombamento, pragas de grãos. 


\section{Introduction}

Reporting experimental errors and methodologies that do not obtain results consistent with those predicted in the objectives, due to problems not identified during the design stage of a study, is as important as publication where the results perfectly expressed the tested hypotheses.

A proposal that should be prioritized by the scientific community is the need to promote the dissemination of experimental errors and methodologies where non-conformities are observed during data collection, which are able to undermine research, and can therefore prevent another researcher from making the same error during both design and performing of a study.

Experiments conducted in laboratory conditions are intended to anticipate possible problems or verify operation of certain situations that may occur under field conditions, allowing for acquisition of results via simulation, which analyzes and describes in controlled conditions the events in controlled situations, as close as possible to real conditions found with the object of study (Marconi and Lakatos, 2003).

In the grain storage sector, insects are considered the main pest organisms and may be basically classified as primary and secondary pests, ranked according to their ability or otherwise to cause damage to intact products.

The order Coleoptera includes a group of insects that present great importance in the grain storage industry, due to the damage they cause in these products, which impairs their quality (Faroni and Silva, 2008). Among the representatives of this group, the species Rhyzopertha dominica (Fabricius, 1792) (Coleoptera: Bostrichidae) and Tribolium castaneum (Herbst, 1797) (Coleoptera: Tenebrionidae) are highlighted. The first due to its ability to attack, injure and nest in intact and healthy grains, and the second due to the large variety of products in which it is found (Athiê and Paula, 2002). Rhyzopertha dominica can be considered the main insect pest species in grains stored around the world (Edde, 2012; Faroni and García-Mari, 1992).

Problems associated with the occurrence of these Bostrichidae have been reported, mainly in tropical and subtropical regions, and may also develop in temperate zones during the warm seasons, where there optimal conditions for their establishment are encountered (Athiê and Paula, 2002; Edde, 2012).

Tribolium castaneum is one of the most important secondary species in storage of cereals in tropical and subtropical regions (Athiê and Paula, 2002), one of the factors that confer this status. Adults of this species can live for many months or even years under optimal conditions of temperature $\left(35^{\circ} \mathrm{C}\right)$ and relative humidity $(75 \%)$. Females oviposit 2 to 10 eggs per day for most of their lives (Subramanyam and Hagstrum, 1996).

Both species, $R$. dominica and $T$. castaneum are the reasons for studies seeking to evaluate responses to the use of insecticides (Aguiar et al., 2010; Furiatti et al., 1999; Pereira et al., 1997, 2003; Pimentel et al., 2012; Pinto
Junior et al., 1997; Santos et al., 2011), control measures (Gonçalves et al., 2000, 2006, 2007; Mariano et al., 2006), forms of repellency (Beckel et al., 2004, 2005; Parvin et al., 2012) and damage caused (Alencar et al., 2011; Silva et al., 2003). In general, these studies present the common fact that they are conducted under simulated conditions in the laboratory, testing the species in the different situations observed in the storage units.

Rhyzopertha dominica and T. castaneum have been studied under different climatic conditions, with variations as needed (Aguiar et al., 2003, 2010; Beckel et al., 2005; Fontes and Arthur, 1994; Gonçalves et al., 2006, 2007; Moino Junior and Alves, 1997; Oliveira et al., 2003, 2006; Silva et al., 2003), and care with the method of simulating the physical structure of the storage unit should be taken into consideration so that the results may express the condition closest to the actual condition (Beckel et al., 2005; Gonçalves et al., 2006, 2007; Ortiz et al., 2012; Pacheco et al., 2009).

In an attempt to simulate the physical conditions of a storage structure are used glassware and recipients that facilitate handling in the laboratory, observing (at the time of its selection) conditions such as material used (glass bottle/jar, Petri-dish, plastic pot/recipient, raffia bag), size of the recipient/arena (height, width, length, diameter), information which can be confirmed in several studies (Aguiar et al., 2003, 2010; Beckel et al., 2005; Belchol and Teixeira, 2007; Fontes and Arthur, 1994; Gonçalves et al., 2006, 2007; Moino Junior and Alves, 1997; Oliveira et al., 2003, 2006; Pereira et al., 2003; Silva et al., 2003).

Studies have been developed on the behavioral response of $R$. dominica, as a function of movement when subjected to compounds for the purposes of control. Some results have shown that these insects may present reduced mobility, remaining at rest for longer periods and also moving shorter distances at slower speeds (Pimentel et al., 2012); others may impair coordination so as to interfere with locating of food, dispersal and migration (Haynes, 1988). Studies submitting these Coleoptera to the control method utilizing an atmosphere modified with ozone $\left(\mathrm{O}_{3}\right)$ showed that this gas does not affect their mobility or movement activity (Grisales, 2013).

It is important to state that in none of the methodologies listed above are there descriptions that relate care with the assurance of insect movement inside the "artificial environment", outside the bulk food substrate. Measures taken to guarantee that these Coleoptera are able to move are those obtained from experimental experience with the insect, for example, always maintaining a thin layer of grain or bran to facilitate its displacement, or covering the surface of the arena with paper or cloth. However, existing studies that relate the movement of insects in the stored product only consider the fact that they are already in contact with the grain mass in the arena (Beckel et al., 2005; Oliveira et al., 2003, 2006). There are no studies that discuss the behavior of adults on flat and smooth surfaces, to which they may be submitted and required to walk or move in laboratory studies. 
Movement of the insect outside the grain mass, on a flat surface presents the need to consider some conditions such as smoothness and roughness of the surface, morphology of the body and locomotor appendages of the insect, which result in the coefficient of friction and stability of walking.

The surfaces of objects, although they appear smooth from a macroscopic point of view, present roughness when microscopically examined, which tends to offer a resistance to movement, called frictional force (Mossmann et al., 2002). This is directly related to the coefficient of friction of the surface, being a relative measure to both bodies (static and dynamic), and dependent on the surface, displacement speed and temperature (Mossmann et al., 2002).

The friction coefficient is relatively small on a smooth surface, and it increases with roughness, just as adherence and stability are better in locations where the coefficient of friction is higher (Serway and Jewett Junior, 2007).

Stability is defined as the state of equilibrium in which the center of support of a body oscillates in a preferred position without changing its orientation with regards to the axis to which it is subjected (Assis, 2008). These axes are imaginary lines that pass through the rigid body, dividing it into three longitudinal plains (related to capacity of frontal displacement), transversal (which act in modification of orientation of the displacement) and vertical (associated with responses of the body to surface irregularities) (Gillespie, 1992).

The axis on the vertical plane, when the body is not at rest, has its oscillation "regulated" by friction (Assis, 2008), and it is on this axis that the major influences on stability of the body are concentrated, and this defines the height of the center of gravity (CG) (Assis and Ravanelli, 2008).

The ratio between width and stability of the body are directly proportional, and the height of the $\mathrm{CG}$ is inversely related to stability, i.e., stability is greatest when the CG is as low as possible for a situation of equal widths (Assis and Ravanelli, 2008).

To estimate stability, when it can be demonstrated that the dimensions of the body are very small relative to the size of Earth, they allow the adoption of simple mathematical models (Assis and Ravanelli, 2008).

Similarly to the study of insect stability, the theory applied to the movement of vehicles in critical situations, can aid in understanding the physical processes involved. The parameter known as the Static Rollover Threshold $(S R T)$ is defined as the maximum lateral acceleration (expressed in g's) in a stationary regime supported by the body before rollover occurs, and is highly influenced by body geometry which decreases with increasing height of the CG for a body of equal width (Wormley et al., 2002). Mathematically, the SRT can be obtained (Equation 1) from the relationship between half the base width by height of the CG (Wormley et al., 2002).

$$
\text { SRTgeom }=\frac{b}{2 h}
$$

where: $S R T_{\text {geom }}=$ static rollover threshold geometric; $b=$ width of the base; and $h=$ height of the center of gravity.
This index is expressed as the maximum lateral acceleration before lateral rollover of the vehicle occurs, where lower values represent the highest risk of rollover (NHTSA, 2002), potentially ranging from 0.4 to 0.6 g's ( $g$ 's $=$ times the acceleration of gravity) for heavy trucks, from 0.8 to $1.1 \mathrm{~g}$ 's for pickup trucks, from 1.1 to $1.5 \mathrm{~g}$ 's for normal automobiles and higher than $1.5 \mathrm{~g}$ 's for sports vehicles (Gillespie, 1992). Thus, it can be observed that the higher the $S R T_{\text {geom }}$ of the object, the more acceleration it supports before rollover, which implies in greater stability.

Thus, this study was developed in order to study the walking stability of $R$. dominica on a flat and smooth surface.

\section{Material and Methods}

A study on feeding preference of the beetles Rhyzopertha dominica and Tribolium castaneum was initiated in the Laboratory of Energy and Stored Grain Pests (LEPGA) of the Universidade Federal de Mato Grosso (UFMT), Sinop University (CUS), municipality of Sinop, Mato Grosso, Brazil. In this work, it was studied the selection behavior of Coleoptera in three conditions. In the first treatment (T1) the Brazil-nut (Bertholletia excelsa Humboldt \& Bonpland) and rice (Oryza sativa L.) were provided as attractive foods in the second (T2) the Brazil-nut and corn (Zea mays L.), and in the third (T3) Brazil-nut and soybeans (Glycine max L. Merril). This experiment was mounted in transparent plastic trays with lids (arenas), measuring $20 \times 20 \times 30 \mathrm{~cm}$ (length $\times$ width $\times$ height), where $30 \mathrm{~g}$ of each substrate were offered to the insects in each condition, and positioned at the two diagonally opposite ends.

In each treatment 25 replicates for each species were established, and 10 adult insects of $R$. dominica and $T$. castaneum were placed at the center of the tray, where their position was monitored for a period of 10 days with evaluation at every 24 hours. However, this study did not present conditions to be completed, since the specimens of $R$. dominica were not able to access the food due to the observed difficulty of locomotion.

Therefore, the researchers decided to study the reasons for why $R$. dominica presented difficulties in walking, which made the original research proposal unfeasible.

Study on the difficulty of walking of $R$. dominica adults was initiated by subjecting these insects to two conditions. In treatment 1 (T1), 10 adults of this Coleoptera were placed at the center of transparent plastic trays with a cover on the flour (arenas) measuring $20 \times 20 \times 20 \mathrm{~cm}$ (length $\mathrm{x}$ width $\mathrm{x}$ height), being offered $30 \mathrm{~g}$ of soybean as food, placed at each diagonal extremity. In treatment 2 (T2 or control), the arena was established without food, to verify mortality due to lack of food. A total of 25 repetitions were performed for each treatment.

A morphological study of $R$. dominica was also initiated in an attempt to determine if the limited mobility was due to the flat, smooth surface of the arena.

Twenty-five unsexed specimens of $R$. dominica were separated and fixed on entomological pins by the use 
of triangles. Next, the body length (BOL), body width (BOW) and body height $(\mathrm{BOH})$ of the insects were measured (Figure 1) using an ocular micrometer coupled to a stereoscopic microscope. Measurements were also made and confirmed by the images generated by the stereoscopic microscope Model Leica EZ4 HD using the software GIMP 2.8.10 on the Windows platform, as well as values obtained from the study of walking stability of the Coleoptera $R$. dominica.

For comparison purposes, unsexed adults of $T$. castaneum were used as a control according to the same procedure performed with $R$. dominica, since it was found that this Coleoptera presents greater ability to move on the flat and smooth surface of the arena.

In the study on walking conditions of $R$. dominica, mortality of this Coleoptera was evaluated to verify if the difficulty in mobility resulted in death of the insects because they were unable to access food. The insect was considered dead when it presented no movement which stimulated by contact with a paintbrush. Data obtained in the treatments ( $\mathrm{T} 1$ and $\mathrm{T} 2$ ) were analyzed in the ASSISTAT 7.7 program (Silva, 2013), submitted to the normality test with $\alpha<0.05$, and then the treatments were compared by the F-test with $p<0.05$.

In study of the morphometric parameters of $R$. dominica and $T$. castaneum, the body measurements (BOL, BOW and $\mathrm{BOH}$ ) were individually compared among the species using the F-test $p<0.05$; and also by the morphometric indices estimated by the discriminant function or first canonical variable (PROC GLM, MANOVA OPTIUM and PROC CANDISC of SAS INSTITUTE, 2005) for the variables, where the morphometric indices were tested by means of the Scheffé test $p<0.05$ (Pimentel-Gomes, 2000). Preceding the analysis, data was submitted to a normality test with $\alpha<0.05$.

Body width and height were employed in determining the $S R T_{\text {aeom }}$, and the values were compared between them and with the range of variation of the static rollover threshold proposed to verify the stability of vehicles, which relates the lateral stability with height of the CG. For the
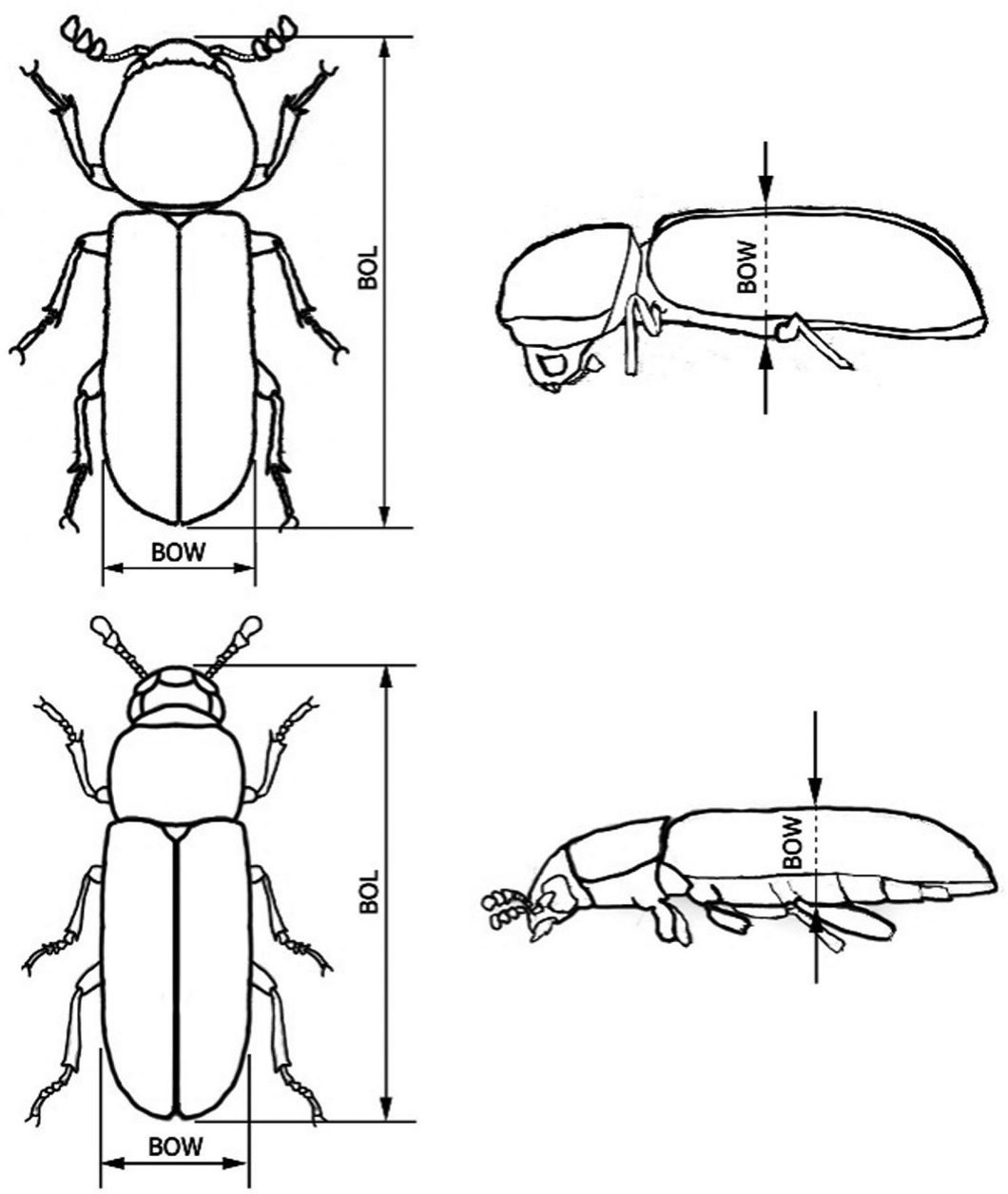

Figure 1. Scan lines of the body measurements of Rhyzopertha dominica (Coleoptera: Bostrichidae) (top) and Tribolium castaneum (Coleoptera: Tenebrionidae) (bottom), on the largest body length (BOL), body width (BOW) and body height (BOH). 
purposes of determining the height of the center of gravity (h) of the insect, in function of its body morphology, it was considered similar to a semicircle, calculating $h$ for this geometric model (Figure 2).

The insect was considered to be overturned when it did not present all its legs supported on the surface, indicated by only the legs on one side or none in contact with the ground plane.

\section{Results}

Mortality of Rhyzopertha dominica adults evaluated in arenas with a flat and smooth surface in the presence and absence of food sources was similar $(\mathrm{F}=1.018 ; p<0.05)$, which may justify that insects died because they were unable to access the food source (Table 1).

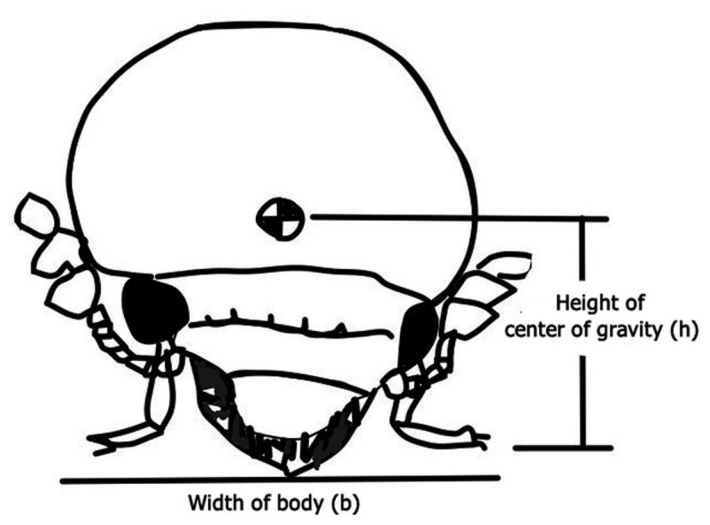

Figure 2. Frontal representation of Rhyzopertha dominica (Coleoptera: Bostrichidae) indicating the similarity of a semicircle with its morphology.
In the morphometric study, it was found that $R$. dominica and $T$. castaneum showed differences in all variables measured: $\mathrm{BOL}(\mathrm{F}=19.62 ; p<0.05)$, BOW $(\mathrm{F}=20.36$; $p<0.05)$ and $\mathrm{BOH}(\mathrm{F}=46.60 ; p<0.05)$ when evaluated separately, and also as a function of morphometric indices (Table 2). In this comparison, R. dominica has lower BOL and $\mathrm{BOW}$, and greater $\mathrm{BOH}$ than the species T. castaneum. Still, in the results observed regarding the morphometric indices generated for the body variables, in all conditions $(\mathrm{W}-\mathrm{H}=0.530383 * \mathrm{~W}-0.068296 \times \mathrm{H}),(\mathrm{L}-\mathrm{H}=0.188674 \times$ $\mathrm{L}+0.001212 \times \mathrm{H})$ and $(\mathrm{H}-\mathrm{L}-\mathrm{W}=-0.017281 \times \mathrm{H}+$ $0,158761 \times \mathrm{L}+0,199343 \times \mathrm{W})$ there were differences in the morphology of the species (Table 2). Along the same lines, the $S R T_{\text {geom }}$ index showed that $R$. dominica may have less stability when walking on a flat and smooth surface when compared with $T$. castaneum (Table 3 ). The differences observed in the morphology of these insects showed that $R$. dominica presented difficulty walking in these conditions, and therefore presented restricted movement, reducing its ability to reach the food substrate.

Regarding morphology of the locomotor appendages (legs and tarsal claws) of $R$. dominica and T. castaneum, morphological differences were not observed to the point that they could be brought into question as the main hypothesis of this study and are considered non-contracting, and are therefore neglected in study of the walking stability.

\section{Discussion}

It was found in this study that adults of $R$. dominica presented difficulties in moving on the flat and smooth surface, spending most of their time turned sideways. This may best explain the observed values related to mortality in the two conditions evaluated (with and without food offered).

Table 1. Mortality of Rhyzopertha dominicain arenas with smooth surface with and without offer of food.

\begin{tabular}{lc}
\hline \multicolumn{1}{c}{ Recipient/arena } & Mortality (days) (Mean \pm SD) \\
\hline Without cover on the flour and with food available & $5.00 \pm 1.04 \mathrm{a}$ \\
Without cover on the flour and no food available (control) & $5.52 \pm 1.04 \mathrm{a}$ \\
\hline
\end{tabular}

Means followed by the same letter do not differ by the F-test with $p<0.05$.

Table 2. Morphometric parameters (length, width and height) and comparison of the relationships between body measurements $(\mathrm{L}=$ length, $\mathrm{W}=$ width, $\mathrm{H}=$ height,) of Rhyzopertha dominica (Coleoptera: Bostrichidae) and Tribolium castaneum (Coleoptera: Tenebrionidae).

\begin{tabular}{lcc}
\hline \multirow{2}{*}{\multicolumn{1}{c}{ Index }} & \multicolumn{2}{c}{ Species } \\
\cline { 2 - 3 } & $\begin{array}{c}\text { Rhyzopertha dominica } \\
\text { (Mean } \pm \text { SD) }\end{array}$ & $\begin{array}{c}\text { Tribolium castaneum } \\
\text { (Mean } \pm \text { SD) }\end{array}$ \\
\hline Length $(\mathrm{mm})$ & $2.252 \pm 0.206 \mathrm{~b}$ & $2.483 \pm 0.161 \mathrm{a}$ \\
Width $(\mathrm{mm})$ & $0.758 \pm 0.046 \mathrm{~b}$ & $0.816 \pm 0.045 \mathrm{a}$ \\
Height $(\mathrm{mm})$ & $0.617 \pm 0.042 \mathrm{a}$ & $0.539 \pm 0.038 \mathrm{~b}$ \\
Variable $(\mathrm{W} \times \mathrm{H})($ dimensionless $)$ & $19.23 \pm 1.10 \mathrm{~B}$ & $24.40 \pm 0.87 \mathrm{~A}$ \\
Variable $(\mathrm{L} \times \mathrm{H})($ dimensionless $)$ & $23.58 \pm 0.75 \mathrm{~B}$ & $31.93 \pm 1.19 \mathrm{~A}$ \\
Variable $(\mathrm{C} \times \mathrm{W} \times \mathrm{H})($ dimensionless $)$ & $27.36 \pm 0.79 \mathrm{~B}$ & $36.32 \pm 1.17 \mathrm{~A}$ \\
\hline
\end{tabular}

Means in the line followed by the same capital letters do not differ by the Scheffé-test with $p<0.05$. Means in the row followed by the same lowercase letters do not differ by the F-test with $p<0.05$. 
Submitting insects to food restriction is a common practice in laboratory studies seeking to study aspects such as the occurrence of cannibalism (Pires et al., 2011), population movements to avoid competition, and also to favor gregarious behavior (Oliveira et al., 2003), mortality or survival time in periods of food restriction (Mourão et al., 2003; Vianna et al., 2010) and the ability to search for new foods (Siekmann et al., 2004). Studies along this same line, but developed with other groups, provided information on the effect of different carbohydrate sources and food deprivation on the biology of wasps of the family Scelionidae and concluded that the food response influences the longevity of the insects, since individuals in this groups presented longevity of at least five times greater when compared to those under food restriction (Meirelles et al., 2009). Females of Cephalonomia stephanoderis (Hymenoptera, Bethylidae) also showed a marked increase in mortality among individuals maintained in experiments with food shortages (Gómez et al., 2012).
Factors such as the flatness and smoothness of the surface provide less friction, and the effect of oscillation on lateral displacement of the body mass with respect to the support surface may increase the risk of rollover (Costa and Leite, 2010). The high CG of $R$. dominica also adds difficulty in moving when there is lack of roughness on the surface, which prevents that this species grab or hold on to the substrate during movement, which is a condition that may guarantee that it does not rollover. This is because during movement the insects have several patterns of movement, even within the same species, but most of the time the movement is made on only three legs so the CG is maintained within the area of influence of the legs (Wilson, 1966). When there occurs movement with change in direction, the insect slows its leg movements on the inside and the legs outside the line curve move faster (Wilson, 1966). In this condition the increase of centrifugal force shift the CG to the external side of the curve (Figure 3), reducing the stability of movement (NHTSA,

Table 3. Static rollover threshold, in g's, of Rhyzopertha dominica and Tribolium castaneum calculated by the Static Rollover Threshold $\left(S R T_{\text {geom }}\right)$ model and compared by the confidence interval with $p<0.05$.

\begin{tabular}{lcc}
\hline & Rhyzopertha dominica & Tribolium castaneum \\
\hline Static Rollover Threshold $\left(S R T_{\text {geom }}\right)(\mathrm{g}$ 's $)$ & $1.446 \mathrm{~b}$ & $1.782 \mathrm{a}$ \\
\hline
\end{tabular}
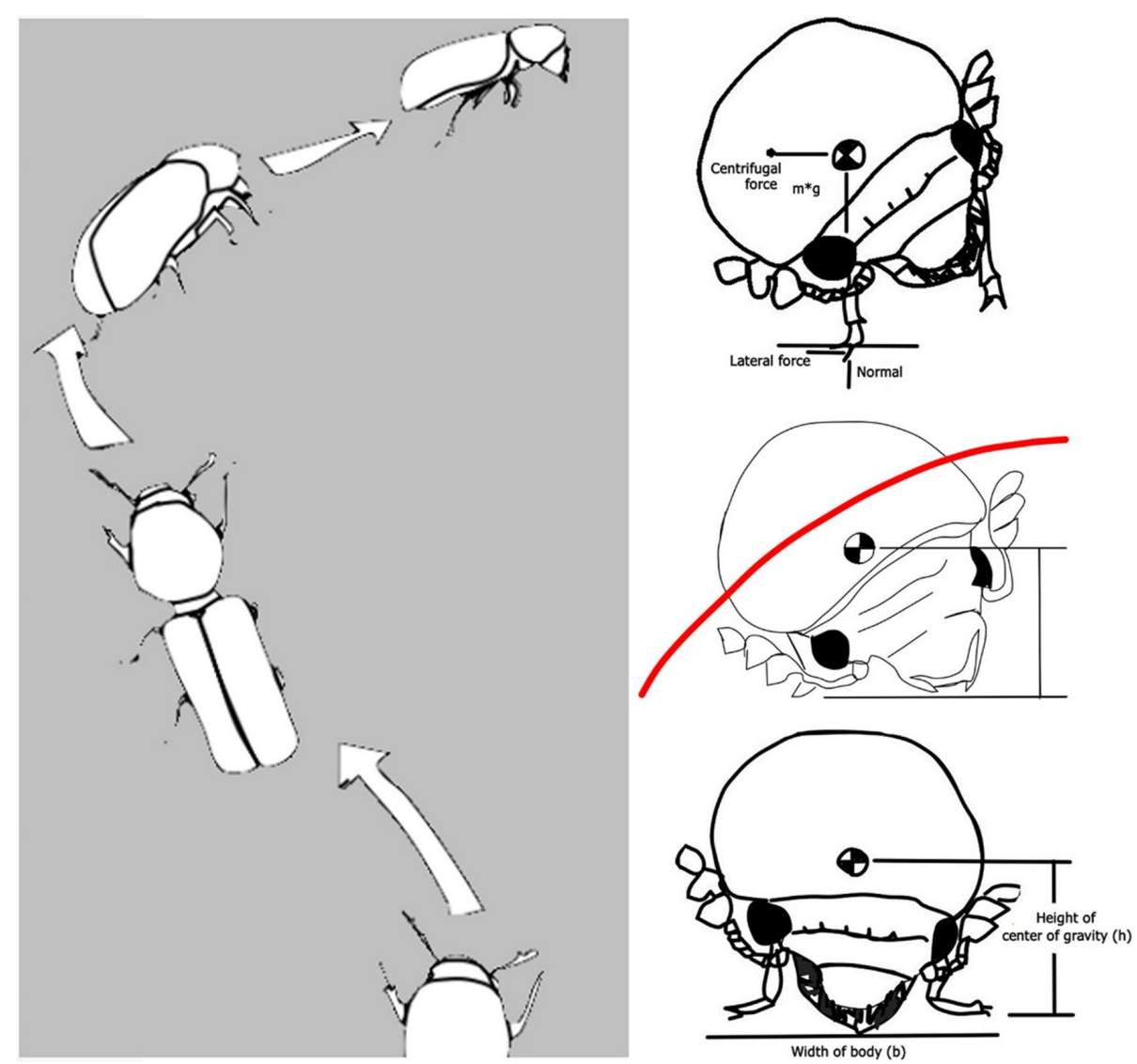

Figure 3. Stages of rollover of Rhyzopertha dominica (Coleoptera: Bostrichidae), due to the lateral action of centrifugal speed as the resistance factor to change in the direction of movement. 
2002). Association of the high CG factor, associated with morphology of $R$. dominica and especially the lack of surface friction, can provide conditions in which there is insufficient force to negate the effects of fluctuations promoted by the change in direction of the insect (Assis, 2008). Moreover, the study on stability by employing the $S R T_{\text {geom }}$ can aid in confirming the hypothesis that this Coleoptera is little stable when walking on a flat and smooth surface, since the morphometric values observed for $\mathrm{BOH}$ and BOW establish a direct relationship with the $S R T_{\text {ge }}$ which may explain the lower stability of $R$. dominica as a result of having a high $\mathrm{CG}$.

The walking stability of $R$. dominica and T. castaneum compared with the Static Rollover Threshold model $S R T_{\text {geom }}$ proposed for vehicles, reveals that proportionalities of the morphological measures of the first insect are similar to a passenger car, while the second insect has the proportional dimension that resemble a sports car, with a lower risk of rollover than the first.

Knowledge of the limitations and utilization of the methodology presented is also important at the time of the laboratory experimental design with $R$. dominica because it influences selection of recipients or adaptations that have greater coefficient of friction when the objective requires that movement/walking of the insect is guaranteed.

The beetle $R$. dominica, although considered a good flyer since field research showed that adults of this Coleoptera dispersed on average up to $375.50 \mathrm{~m}$ from the point of release in a wooded environment and $333.97 \mathrm{~m}$ from the point of origin in locations without trees (Mahroof et al., 2010), when there are limitations to its movement by air it is required to walk. On flat and smooth surfaces, similar to those of laboratory bioassays, care must be taken since movement of this Coleoptera is highly impaired by factors related to adherence in relation to its body shape, due to the fact of its displaced $\mathrm{CG}$, resulting in imbalance and consequent rollover while walking. Thus, it may be suggested that greater care is taken in studies on this species, especially in relation to the type of surface on which the individual will be evaluated.

\section{References}

AGUIAR, R.W.S., FARONI, L.R.D.A., GUEDES, R.N.C., SOUSA, A.H. and ROZADO, A.F., 2010. Toxicidade da combinação de dióxido de carbono e fosfina sob diferentes temperaturas para Tribolium castaneum. Revista Brasileira de Engenharia Agrícola e Ambiental, vol. 14, no. 8, pp. 881-886. http://dx.doi.org/10.1590/ S1415-43662010000800013.

AGUIAR, R.W.S., OLIVEIRA, C.R.F., MATOS, C.H.C., and FARONI, L.R.D.A., 2003. Uso do congelamento no controle de insetos-praga de grãos armazenados. Bioscience Journal, vol. 19 , no. 2, pp. 21-25.

ALENCAR, E.R., FARONI, L.R.D.A., FERREIRA, L.G., COSTA, A.R. and PIMENTEL, M.A.G., 2011. Qualidade de milho armazenado e infestado por Sitophilus zeamais e Tribolium castaneum. Revista Engenharia na Agricultura, vol. 19, no. 1, pp. 9-18. http://dx.doi.org/10.13083/1414-3984.v19n01a01.
ASSIS, A.K.T., 2008. Arquimedes, o centro de gravidade e a lei da alavanca. 1st ed. Quebec: Apeiron Montreal. 236 p.

ASSIS, A.K.T., and RAVANELLI, F.M.M., 2008. Reflexões sobre o conceito de centro de gravidade nos livros didáticos. Ciência \& Ensino, vol. 2, no. 2, pp. 1-11.

ATHIÊ, I. and PAULA, D.C., 2002. Insetos de grãos armazenados: aspectos biológicos e identificação. 2nd ed. São Paulo: Livraria Varela. 244 p.

BECKEL, H., LORINI, I. and LAZZARI, S.M.N., 2004. Comportamento de adultos de diferentes raças de Rhyzopertha dominica (Fabricius) (Coleoptera, Bostrichidae) em superfície tratada com deltamethrin. Revista Brasileira de Entomologia, vol. 48 , no. 1 , pp. 115-118. http://dx.doi.org/10.1590/S008556262004000100019 .

BECKEL, H., LORINI, I. and LAZZARI, S.M.N., 2005. Efeito de repelência do inseticida deltramethrin sobre insetos de raças resistentes e suscetíveis de Rhyzopertha dominica (Fabricius) (Coleoptera, Bostrichidae) em grãos de trigo armazenado. Revista Brasileira de Entomologia, vol. 49, no. 4, pp. 572-574. http:// dx.doi.org/10.1590/S0085-56262005000400018.

BELCHOL, F.S. and TEIXEIRA, I.R.V., 2007. Preferência alimentar, performance e aceitabilidade de Tribolium castaneum (Coleoptera, Tenebrionidae) na farinha de soja integral. Reviews in Analgesia, vol. 28, no. 1, pp. 38-41.

COSTA, E.V. and LEITE, C.A.F., 2010. Deslocamento da força normal à superfície de apoio a um corpo em equilíbrio na presença da força de atrito. Revista Brasileira de Ensino de Física, vol. 32, no. 4, pp. 4301-4303.

EDDE, P.A., 2012. A review of the biology and control of Rhyzopertha dominica (F.) the lesser grain borer. Journal of Stored Products Research, vol. 48, no. 1, pp. 1-18. http://dx.doi. org/10.1016/j.jspr.2011.08.007

FARONI, L.R.D.A. and GARCÍA-MARI, F., 1992. Influencia de la temperatura sobre los parámetros biológicos de Rhyzopertha dominica (F.). Boletin de Sanidad Vegetal, vol. 18, no. 2, pp. 455-467.

FARONI, L.R.D.A. and SILVA, J.S., 2008. Manejo de pragas no ecossistema de grãos armazenados. In: J.S. SILVA. Secagem e armazenagem de produtos agrícolas. 2 nd ed. Viçosa: Aprenda Fácil, pp. 371-406.

FONTES, I.S. and ARTHUR, V., 1994. Efeitos da radiação gama do cobalto-60 em ovos de Tribolium castaneum (Herbst., 1797) (Coleoptera, Tenebrionidae). Scientia Agrícola, vol. 51, no. 3, pp. 403-406. http://dx.doi.org/10.1590/S0103-90161994000300004.

FURIATTI, R.S., PEREIRA, P.R.V.S., PINTO JUNIOR, J.R. and LAZZARI, F.A., 1999. Avaliação de inseticidas no controle de Sitophilus oryzae (Linnaeus) (Coleoptera, Curculionidae), e Rhyzopertha dominica (Fabricius) (Coleoptera, Bostrichidae) em trigo armazenado. Revista Brasileira de Zoologia, vol. 16, no. 1, pp. 221-226. http://dx.doi.org/10.1590/S0101-81751999000100018.

GILLESPIE, T.D., 1992. Fundamentals of vehicle dynamics. Warrendale: SAE International. 519 p. http://dx.doi.org/10.4271/R-114.

GÓMEZ, J., BARRERA, J.F., LIEDO, P. and VALLE, J., 2012. Influence of age and diet on the performance of Cephalonomia stephanoderis (Hymenoptera, Bethylidae) a parasitoid of the coffee berry borer, Hypothenemus hampei (Coleoptera, Curculionidae). Revista Brasileira de Entomologia, vol. 56, no. 1, pp. 95-100. http://dx.doi.org/10.1590/S0085-56262012005000017. 
GONÇALVES, J.R., FARONI, L.R.D.A., GUEDES, R.N.C., OLIVEIRA, C.R.F. and SILVA, R.M., 2007. Suscetibilidade de Rhyzopertha dominica (Fabricius) (Coleoptera, Bostrichidae) ao enxofre. Ciência Rural, vol. 37, no. 4, pp. 1145-1148. http:// dx.doi.org/10.1590/S0103-84782007000400037.

GONÇALVES, J.R., FARONI, L.R.D.A., GUEDES, R.N.C., OLIVEIRA, C.R.F. and GARCIA, F.M., 2006. Associação de deltrametrina com Acarophenax lacunatus e seu impacto sobre o desenvolvimento de Rhyzopertha dominica. Pesquisa Agropecuária Brasileira, vol. 41, no. 8, pp. 1235-1240. http:// dx.doi.org/10.1590/S0100-204X2006000800004.

GONÇALVES, R.A., SANTOS, J.P., CHANDRA, P.K. and GERMANI, R., 2000. Controle de Rhyzopertha dominica pela atmosfera controlada com $\mathrm{CO}_{2}$ em trigo. Pesquisa Agropecuária Brasileira, vol. 35, no. 1, pp. 1-9. http://dx.doi.org/10.1590/ S0100-204X2000000100001.

GRISALES, L.P.V., 2013. Toxicidade e respostas comportamentais ao ozônio em populações de Rhyzopertha dominica. Viçosa: Universidade Federal de Viçosa, 32 p. Masters Dissertation.

HAYNES, K.F., 1988. Sublethal effects of neurotoxic insectides on insect behavior. Annual Review of Entomology, vol. 33, no. 1, pp. 149-168. http://dx.doi.org/10.1146/annurev.en.33.010188.001053. PMid:3277528.

MAHROOF, R.M., EDDE, P.A., ROBERTSON, B., PUCKETTE, J.A. and PHILLIPS, T.W., 2010. Dispersal of Rhyzopertha dominica (Coleoptera: Bostrichidae) in different habitats. Environmental Entomology, vol. 39, no. 3, pp. 930-938. http://dx.doi.org/10.1603/ EN09243. PMid:20550808.

MARCONI, M.A. and LAKATOS, E.M., 2003. Fundamentos de metodologia cientifica. 5th ed. São Paulo: Atlas. 312 p.

MARIANO, F.D., SANTOS, S. and SANTOS, F.F.S., 2006. Utilização de terra de diatomácea como alternativa no controle de insetos em grãos de trigo armazenados. Reviews in Analgesia, vol. 24 , no. 1 , pp. $60-64$.

MEIRELLES, A.P., CARNEIRO, T.R. and FERNANDES, O.A., 2009. Efeito de diferentes fontes de carboidrato e da privação de alimento sobre aspectos biológicos de Telenomus remus Nixo (Hymenoptera, Scelionidae). Revista Brasileira de Entomologia, vol. 53, no. 3, pp. 457-460. http://dx.doi.org/10.1590/S008556262009000300022 .

MOINO JUNIOR, A. and ALVES, S.B., 1997. Determinação de concentrações de Beauveria bassiana (Bals.) Vuill. para o controle de insetos-pragas de grãos armazenados. Anais da Sociedade Entomológica do Brasil, vol. 26, no. 1, pp. 15-20. http://dx.doi. org/10.1590/S0301-80591997000100002.

MOSSMANN, V.L.F., CATELLI, K.B.M.F., LIBARDI, H. and DAMO, I.S., 2002. Determinação dos coeficientes de atrito estático e cinético utilizando-se a aquisição automática de dados. Revista Brasileira de Ensino de Física, vol. 24, no. 2, pp. 146-149. http:// dx.doi.org/10.1590/S1806-11172002000200010.

MOURÃO, S.A., ZANUNCIO, J.C., MOLINA-RUGAMA, A.J., VILELA, E.F. and LACERDA, M.C., 2003. Efeito da escassez de presa na sobrevivência e reprodução do predador Supputius cincticeps (Stål) (Heteroptera, Pentatomidae). Neotropical Entomology, vol. 32, no. 3, pp. 469-473. http://dx.doi.org/10.1590/ S1519-566X2003000300014.

NATIONAL HIGHWAY TRAFFIC SAFETY ADMINISTRATION - NHTSA, 2002. Rating system for rollover resistance: an assessment. Washington. 261 p. Special Report, no. 265.
OLIVEIRA, C.R.F., FARONI, L.R.D.A., GUEDES, R.N.C., PALLINI, A. and GONÇALVES, J.R., 2006. Dispersão de Acarophenax lacunatus (Cross \& Krantz) (Prostigmata: Acarophenacidae) em trigo armazenado, sob condições artificiais. Neotropical Entomology, vol. 35, no. 4, pp. 536-541. http://dx.doi.org/10.1590/ S1519-566X2006000400017. PMid:17061804.

OLIVEIRA, C.R.F., MATOS, C.H.C., AGUIAR, R.W.S., and FARONI, L.R.D.A., 2003. Dispersão de Tribolium castaneum (Herbst) (Coleoptera: Tenebrionidae) e Sitophilus zeamais Motschulsky (Coleoptera, Curculionidae) em trigo armazenado. Bioscience Journal, vol. 19, no. 3, pp. 51-57.

ORTIZ, M., SILVA A, G., TAPIA V, M., RODRIGUEZ M, J.C., LAGUNES T, A., SANTILLÁN-ORTEGA, C., ROBLESBERMÚDEZ, A. and AGUILAR-MEDEL, S., 2012. Toxicity of Boldo Peumus boldus Molina for Sitophilus zeamais Motschulsky and Tribolium castaneum Herbst. Chilean Journal of Agricultural Research, vol. 72, no. 3, pp. 345-349. http://dx.doi.org/10.4067/ S0718-58392012000300007.

PACHECO, R.A., SÁNCHEZ, E.S., SÁNCHEZ, G.G. and SUÁREZ, Y.M., 2009. Vulnerabilidad de la semilla de arroz al ataque de Rhyzopertha dominica (F.) (Coleoptera: Bostrichidae). Fitosanidad, vol. 13, no. 1, pp. 7-10.

PARVIN, S., ZENG, X.N. and ISLAM, T., 2012. Bioatividade do mogno da Indonésia, Toonasureni (Blume) (Meliaceae), contra o besouro-das-farinhas, Tribolium castaneum (Coleoptera, Tenebrionidae). Revista Brasileira de Entomologia, vol. 56, no. 3, pp. 354-358. http://dx.doi.org/10.1590/S0085-56262012005000047.

PEREIRA, P.R.V.S., FURIATTI, R.S., LAZZARI, F.A. and PINTO JUNIOR, A.R., 1997. Avaliação de inseticidas no controle de Sitophilus oryzae (L.) (Coleoptera, Curculionidae) e Rhyzopertha dominica (Fab.) (Coleoptera, Bostrichidae) em milho armazenado. Anais da Sociedade Entomológica do Brasil, vol. 26, no. 3, pp. 411-416. http://dx.doi.org/10.1590/S0301-80591997000300001.

PEREIRA, P.R.V.S., PINTO JUNIOR, A.R., and FURIATTI, R.S., 2003. Eficiência de inseticidas no controle de Sitophilus oryzae (L.) (Coleoptera, Curculionidae), e Rhyzopertha dominica (Fab.) (Coleoptera, Bostrichidae) em cevada armazenada. Revista Acadêmica. Ciências Agrárias e Ambientais, vol. 1, no. 3, pp. 65-71.

PIMENTEL, M.A.G., FARONI, L.R., CORRÊA, A.S. and GUEDES, R.N., 2012. Phosphine-induced walking response of the lesser grain borer (Rhyzopertha dominica). Pest Management Science, vol. 68, no. 10, pp. 1368-1373. http://dx.doi.org/10.1002/ ps.3314. PMid:22615260.

PIMENTEL-GOMES, F., 2000. Curso de estatística experimental. 15th ed. Piracicaba: Escola Superior de Agricultura "Luiz de Queiroz", FEALQ, Universidade de São Paulo. 451 p.

PINTO JUNIOR, J.R., FURIATTI, R.S., PEREIRA, P.R.V.S. and LAZZARI, F.A., 1997. Avaliação de inseticidas no controle de Sitophilus oryzae (L.) (Coleoptera, Curculionidae), e Rhyzopertha dominica (Fab.) (Coleoptera, Bostrichidae) em arroz armazenado. Anais da Sociedade Entomológica do Brasil, vol. 26, no. 2, pp. 285-290. http://dx.doi.org/10.1590/S0301-80591997000200009.

PIRES, E.M., ZANUNCIO, J.C. and SERRÃO, J.E., 2011. Cannibalism of Brontocoris tabidus and Podisus nigrispinus (Heteroptera, Pentatomidae) on periods of pre-release without food or fed with Eucalyptus cloeziana plants. Phytoparasitica, vol. 39, no. 1, pp. 27-34. http://dx.doi.org/10.1007/s12600-010-0132-6.

SANTOS, J.C., FARONI, L.R.A., SOUSA, A.H. and GUEDES, R.N.C., 2011. Fumigant toxicity of allyl isothiocyanate to populations of the red flour beetle Tribolium castaneum. Journal 
of Stored Products Research, vol. 47, no. 3, pp. 238-243. http:// dx.doi.org/10.1016/j.jspr.2011.03.004.

SAS INSTITUTE, 2005. SAS system for windows: version 9.0. Cary: SAS Institute. Software.

SERWAY, R.A. and JEWETT JUNIOR, J.W., 2007. Princípios de física: mecânica clássica. 3rd ed. São Paulo. Thomson Learning. $403 \mathrm{p}$.

SIEKMANN, G., KELLER, M.A. and TENHUMBERG, B., 2004. The sweet tooth of adult parasitoid Cotesia rubecula: ignoring hosts for nectar? Journal of Insect Behavior, vol. 17, no. 4, pp. 459-476. http://dx.doi.org/10.1023/B:JOIR.0000042535.76279.c7.

SILVA, A.A.L., FARONI, L.R.D.A., GUEDES, R.N.C., MARTINS, J.H. and PIMENTEL, M.A.G., 2003. Modelagem das perdas causadas por Sitophilus zeamais e Rhyzopertha dominica em trigo armazenado. Revista Brasileira de Engenharia Agrícola e Ambiental, vol. 7, no. 2, pp. 292-296. http://dx.doi.org/10.1590/ S1415-43662003000200018.

SILVA, F.A.S., 2013. ASSISTAT versão 7.7 beta. Campina Grande: Universidade Federal de Campina Grande. Software.
SUBRAMANYAM, B. and HAGSTRUM, D.W., 1996. Coleoptera. In: B. SUBRAMANYAM and D.W. HAGSTRUM. Integrated management of insects in stored products. New York: Marcel Dekker. 39 p.

VIANNA, U.R., PRATISSOLI, D., ZANUNCIO, J.C., ALENCAR, J.R.C.C. and ZINGER, F.D., 2010. Privação de hospedeiro e alimentação sobre as características reprodutivas de Trichogramma atopovirilia (Hymenoptera: Trichogrammatidae). Idesia, vol. 28, no. 2, pp. 83-88.

WILSON, D.M., 1966. Insect walking. Annual Review of Entomology, vol. 11, no. 1, pp. 103-122. http://dx.doi.org/10.1146/ annurev.en.11.010166.000535. PMid:5321575.

WORMLEY, D.N., BAUER, K.M., BARNARD, J.E., BOSTRON, A., FREGUSON, S.A., GARRICK, B.J., GREEN, P.A., HARKEY, D.L., HEDRICK, J.K., HOLLOWAY, D.C., METZ, L.D., SAVIN, N.E. and THOMPSON, K.M., 2002. Rating system for rollover resistance. Washington: National Highway Traffic Safety Administration, Transport Research Board. 135 p. Special Report, no. 265. 